\title{
電子式ハンドル型電動車いすの開発 一動作設定項目の検討一
}

Development of a powered wheelchair using electronically connected handle

-Setting parameters for operation-

\author{
○藤井 雄介 ${ }^{1}$, 垣本 映 ${ }^{1}$, 鈴木 重信 ${ }^{1}$, 関口 行雄 ${ }^{1}$, 松野 史幸 ${ }^{2}$ \\ 1. 職業能力開発総合大学校 2.（株）コーヤシステムデザイン
}

Yusuke Fujii, Akira Kakimoto, Shigenobu Suzuki, Yukio Sekiguchi, Fumiyuki Matuno

The Polytechnic University, Koya System Desingn

\section{1. はじめに}

加齢による身体的機能低下で自力歩行が難しくなってきた高 齢者を対象とした電動車いすの開発を目指し研究を行っている. この電動車いすは操作方法や運転条件などを使用者個々人の 希望に合わせて選択できるようなシステムが良いという観点から， 電子式ハンドル型電動車いすとして試作された1). しかしながら, 使用者に合わせた設定機能が不十分でプログラムによる実現とス イッチによる簡単な設定が望まれる. また設定機能の評価等のた めに運転状態の記録が必要であると考えた. 今回これらの機能を 実現し走行テストを行って評価したので報告する.

\section{2. 電子式ハンドル}

電子式ハンドルは, ハンドル式操作装置を市販のジョイスティツ ク式電動車いすの駆動ベースに組込み, ハンドル式操作装置で 駆動する方式である. 電子式ハンドルの最大の特徵は, ハンドル から軸が直接前輪に慗がるのではなく, ハンドルの回転角度をポ テンショメータによって検出し,2輪の駆動ベースの回転比に変換 して駆動することである. そのため, 操作感覚は自転車に近く, 回 転半径を小さくでき軽量化も図れる. また, 操作力の軽減, 遊び や感度を任意に設定できるというメリットもある。

\section{3. 動作設定項目}

市販の電動車いすを参考に, 最高速度, 加速・減速時間, 走 行操作不感帯 (ハンドルの遊び角), ハンドルの感度の設定を可 能にした.これらの設定はハンドルに取り付けたロータリースイッ チで停止時に変更できるようにした. 最高速度は, 直進時の最高 速度のことで, 設定範囲は $4.24 \mathrm{~km} / \mathrm{h}$ を 16 段階で調節可能にした。 加速時間は, 指示速度 0 から最高速度に達するまでの時間, 減 速時間は最高速度から 0 になるまでの時間で, 設定範囲は 0.5〜 8 秒まで 0.5 秒ごとに 10 段階で調節可能にした. 指示速度とはプ ログラムで車いす本体コントローラに対し指示する速度から換算し た車いす中心部分での速度である. 走行操作不感帯はハンドル の遊び角で, ハンドル角を変えても直進をする範囲である. 設定 範囲は操作可能角度の $\pm 9 \mathrm{deg}$ まで $\pm 1 \mathrm{deg}$ ごとに 10 段階. 数值が 高いほど走行操作不感帯が多くなる. 感度はハンドルの操作指

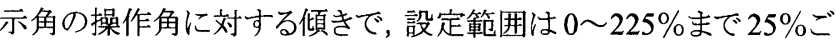
とに 10 段階としている. 設定項目と設定範囲を Table 1 に示寸.

\section{4. 運転状態の記録}

ハンドル操作時の操作角度と指示速度を記録できるようにし

Table 1 設定項目と設定範囲

\begin{tabular}{|c|c|}
\hline 設定項目 & 設定範囲 \\
\hline 最高速度 & 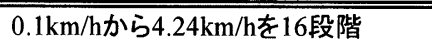 \\
\hline 減速時間 & 0.5 秒から 8 秒まで 0.5 秒ごとに16段階 \\
\hline 加速時間 & 0.5秒から 5 秒まで 0.5 秒ごとに10段階 \\
\hline 感度 & 0\%から225\%まで25\%ごとに10段階 \\
\hline 走行操作不感帯 & 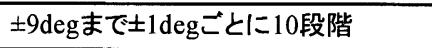 \\
\hline
\end{tabular}

た. また比較のため, ジョイステイックでも同様に記録できるように した. 8 の字走行時の結果として記録例を示す. ハンドルの方向 角度を Fig.1, ジョイステイック方向角度を Fig.2, ハンドルの指示 速度を Fig.3，ジョイステイツクの指示速度を Fig.4 に示す. 設定は 最高速度 $4.24 \mathrm{~km} / \mathrm{h}$, ハンドル操作時の加速時間 2 秒, 减速時間 1 秒である. またハンドル操作時では, ジョイステイツクで左右方向 に倒した時と同様, ハンドル角度に応じて速度低下が生じる

操作角度は反時計回りに右 $0^{\circ}$, 正面 $90^{\circ}$, 左 $180^{\circ}$ としている. 全走行時間はほぼ同じで, 方向角度の波形についても変化がほ ぼ一致している. 次に指示速度をみる. 最高速度に関して, ジョイ スティックとハンドルのグラフの最高值が共に設定值の $4.24 \mathrm{~km} / \mathrm{h}$ 付近になっている.これにより, ジョイスティックとハンドルの最高 速度につき設定值との一致が確認できる. 次にハンドル操作時の 加速・减速時間に関して, $0 \mathrm{~km} / \mathrm{h}$ から最高速度まで上昇する時間 をみると, 2 秒程度になっている. また, 減速時間についても 1 秒 程度になっている.これにより, ハンドル操作時の加速・減速時間 の設定値との一致が確認できる.

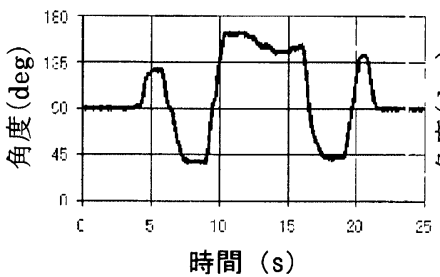

Fig.1 ハンドルの方向角度

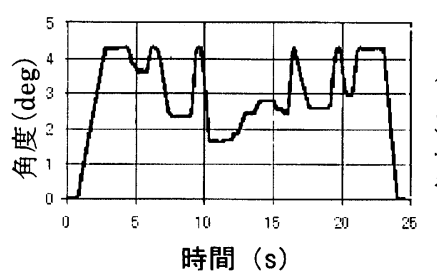

Fig.3 ハンドルの指示速度

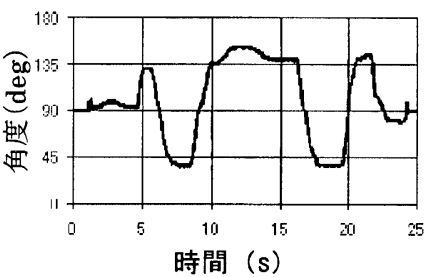

Fig.2 ジョイスティックの方向角度

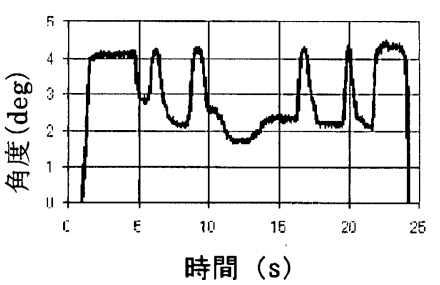

Fig.4 ジョイスティックの指示速度

\section{5. まとめ}

動作設定項目を選定し, ロータリースイッチで可変する機能を 実現した. 運転状態の記録についてはジョイステイックも含め確認 できた. 今後の課題として, ハンドルの操作力, ユーザーや使用 環境に合わせた設定値について検討する予定である.

\section{謝辞}

本研究は, テクノエイド協会福祉用具研究開発助成事業による ことを記し謝意を表する.

\section{<参考文献>}

1) 鈴木重信: 高齢者の電動車いす運転能力特性に関する研究, 第4回生活支援工学系学会連合大会講演予稿集, 2006, 165 